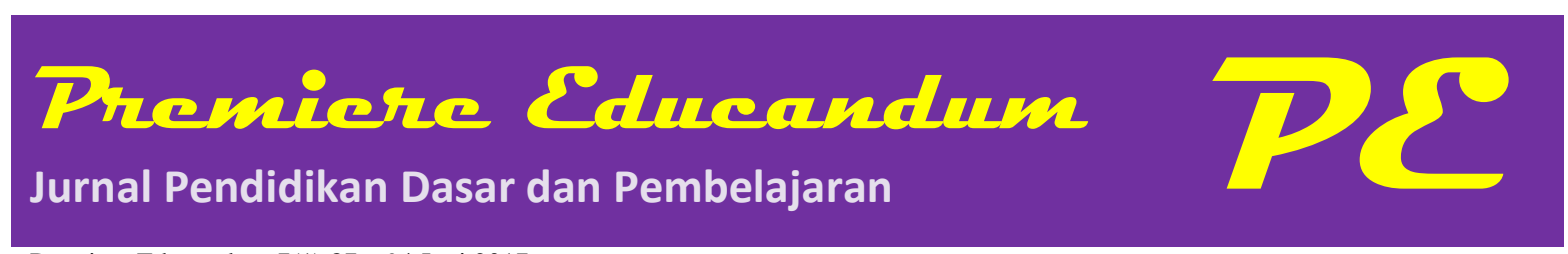

Premiere Educandum 7(1) 87 - 94 Juni 2017

Copyright @2017 PGSD Universitas PGRI Madiun

P - ISSN: 2088-5350/E - ISSN: 2528-5173

Available at: http://e-journal.unipma.ac.id/index.php/PE

\title{
Penggunaan Metode Kooperatif Model Team Games Tournament Untuk Meningkatkan Kemampuan Belajar Berhitung Perkalian dan Pembagian Siswa Kelas II
}

\author{
Yayuk Hermi Setyowati ${ }^{1)}$ \\ ${ }^{1}$ SD Negeri 1 Taman Madiun \\ email: yuyun165@yahoo.com
}

\begin{abstract}
The purpose of this study is to determine the improvement of the ability of second grade students in the second semester in understanding multiplication learning and division on mathematics subjects using cooperative method of team games tournament model. Classroom Action Research was conducted in Class II Semester II SDN 0I Taman Kecamatan Taman Kota Madiun. The subject of this research was the second grade students of SDN OI Taman Kecamatan Taman Kota Madiun with a total of 30 students. Action plans to be undertaken in this classroom action research were: Planning, Action Implementation, Observation and Interpretation, Analysis and Reflection. In analyzing data is by analyzing observation result of learning then done interpretation based on literature review and teacher experience. In the reflection, data analysis of the process, problems, and obstacles encountered is followed by reflection on the impact of the implementation of the action being carried out. From the results of learning activities that have been done for two cycles, and based on all the discussion and analysis that has been done, it can be concluded that learning with cooperative TGT model can improve student learning achievement marked by the improvement of students' learning mastery in every cycle. It is characterized by increasing the average success of students in each cycle that is cycle I average 6.6 to 8.4 in cycle II.
\end{abstract}

Keywords: TGT, Classroom action research, Students' mathematic result.

\begin{abstract}
Abstrak
Tujuan penelitian ini adalah untuk mengetahui peningkatan kemampuan siswa kelas II semester II dalam memahami pembelajaran perkalian dan pembagian pada mata pelajaran matematika menggunakan metode kooperatif model team games tournament. Penelitian Tindakan Kelas ini dilakukan di Kelas II Semester II SDN 0I Taman Kecamatan Taman Kota Madiun. Subjek Penelitian ini adalah siswa kelas II SDN 0I Taman Kecamatan Taman Kota Madiun dengan jumlah siswa 30 orang. Rencana tindakan yang akan dilakukan dalam penelitian tindakan kelas ini adalah: Perencanaan , Implementasi Tindakan, Observasi dan Interpretasi, Analisis dan Refleksi. Adapun cara menganalisis data adalah dengan menganalisis data hasil obeservasi pembelajaran kemudian dilakukan penafsiran berdasarkan kajian pustaka dan pengalaman guru. Pada bagian refleksi dilakukan analisis data mengenai proses, masalah, dan hambatan yang dijumpai kemudian dilanjutkan dengan refleksi dampak pelaksanaan tindakan yang dilaksanakan. Dari hasil kegiatan pembelajaran yang telah dilakukan selama dua siklus, dan berdasarkan seluruh pembahasan serta analisis yang telah dilakukan dapat disimpulkan bahwa pembelajaran dengan kooperatif model TGT dapat meningkatkan prestasi belajar siswa yang ditandai dengan peningkatan ketuntasan belajar siswa dalam setiap siklus. Hal tersebut ditandai dengan meningkatnya rata-rata keberhasilan siswa pada tiap-tiap siklus yaitu siklus I rata-rata 6,6 menjadi 8,4 pada siklus II.
\end{abstract}

Kata Kunci: TGT, PTK, Hasil belajar Matematika. 


\section{A. PENDAHULUAN}

Dalam pembelajaran matematika agar mudah dimengerti oleh siswa, digunakan proses penalaran deduktif untuk menguatkan pemahaman yang sudah dimiliki oleh siswa. Tujuan pembelajaran matematika adalah melatih cara berfikir secara sistematis, logis, kritis, kreatif dan konsisten.

Menurut Masrukan (dalam Fasilitator, 2004:32), pembelajaran matematika harus dilakukan sesuai dengan kondisi atau kebutuhan siswa. Pembelajaran akan berhasil dan efektif jika pembelajaran itu melibatkan siswa secara aktif. Belajar matematika adalah berpikir dan berbuat (mengerjakan matematika) bukan sekedar mendengar. Untuk itu perlu ada metode pembelajaran yang melibatkan siswa secara langsung dalam pembelajaran. Adapun metode yang dimaksud adalah metode pembelajaran kooperatif.

Menurut Lie (2004:18) metode pembelajaran kooperatif adalah suatu model pembelajaran dengan menggunakan sistem kerja atau belajar kelompok yang terstruktur. Model pembelajaran kooperatif tidak sama dengan sekedar belajar dalam kelompok. Ada unsur-unsur dasar dalam pembelajaran kooperatif yang membedakannya dengan pembagian kelompok asal-asalan. Pelaksanaan prosedur model pembelajaran kooperatif dengan benar akan memungkinkan guru mengelola kelas lebih efektif.

Salah satu model dalam metode kooperatif adalah TGT (Teams Games Tournament). TGT adalah Team Games Tounament (TGT) adalah salah satu tipe atau model pembelajaran kooperatif yang mudah diterapkan, melibatkan aktivitas seluruh siswa tanpa harus ada perbedaan status. (Kiranawati, 2007)
Aktivitas belajar dengan permainan yang dirancang dalam pembelajaran kooperatif model TGT memungkinkan siswa dapat belajar lebih rileks di samping menumbuhkan tanggung jawab, kerja sama, persaingan sehat dan keterlibatan belajar.

Gagasan utama dibalik model TGT adalah untuk memotivasi siswa, mendorong dan membantu satu sama lain agar menguasai keterampilan-keterampilan yang disajikan oleh guru. Jika siswa menginginkan agar kelompok mereka memperoleh penghargaan, mereka harus membantu teman sekelompoknya mempelajari materi yang diberikan. Mereka harus mendorong teman mereka untuk melakukan yang terbaik dan menyatakan suatu norma bahwa belajar itu merupakan suatu yang penting, berharga, dan menyenangkan.

Berdasarkan hasil pengamatan kepada siswa kelas II SDN 01 Taman pada saat pembelajaran Matematika dengan kompetensi dasar berhitung perkalian dan pembagian, pemahaman siswa terhadap materi tersebut masih rendah. Hal ini dapat dilihat dari hasil test yang dilaksanakan setelah pengenalan konsep yaitu 30 siswa hanya 9 anak di kelas yang memperoleh nilai 7 keatas. Dengan demikian dapat dikatakan, sebagian besar siswa kurang menguasai materi yang dibahas, yaitu belum memenuhi kriteria $75 \%$.

Oleh karena itu, diperlukan suatu inovasi pemanfaatan model pembelajaran, yaitu dengan menggunakan model TGT dalam pembelajaran Matematika.

Adapun tujuan dari penelitian ini adalah untuk mengetahui:

a. Pelaksanaan pembelajaran perkalian dan pembagian pada mata pelajaran Matematika dengan menggunakan 
metode kooperatif model team games tournament

b. Peningkatan kemampuan siswa kelas II semester II dalam memahami pembelajaran perkalian dan pembagian pada mata pelajaran matematika menggunakan metode kooperatif model team games tournament.

\section{B. METODE PENELITIAN}

Penelitian Tindakan Kelas ini dilakukan di Kelas II Semester II SDN 0I Taman Kecamatan Taman Kota Madiun. Subjek Penelitian ini adalah siswa kelas II SDN 0I Taman Kecamatan Taman Kota Madiun dengan jumlah siswa 30 orang. Rencana tindakan yang akan dilakukan dalam penelitian tindakan kelas ini adalah sebagai berikut.

1. Perencanaan

2. Implementasi Tindakan

3. Observasi dan Interpretasi

4. Analisis dan Refleksi

Selanjutnya, data diambil dengan cara melihat perkembangan dan hasil belajar siswa dari tiap-tiap siklus, kemudian membuat perencanaan perbaikan untuk meningkatkan kemampuan siswa melalui masing-masing tes mulai dari siklus I sampai dengan siklus II

Instrumen penelitian yang digunakan dalam penelitian ini adalah:

1. Rencana Pembelajaran

2. Lembar Tes

3. Lembar Observasi

Adapun cara menganalisis data adalah dengan menganalisis data hasil obeservasi pembelajaran kemudian dilakukan penafsiran berdasarkan kajian pustaka dan pengalaman guru. Pada bagian refleksi dilakukan analisis data mengenai proses, masalah, dan hambatan yang dijumpai kemudian dilanjutkan dengan refleksi dampak pelaksanaan tindakan yang dilaksanakan.

\section{HASIL DAN PEMBAHASAN \\ Siklus 1}

Siklus I dilaksanakan dengan 2 kali pertemuan. Berikut adalah hasil pelaksanan siklus 1

a. Menyusun Rencana Tindakan I

Identifikasi masalah dilakukan setelah observasi proses belajar mengajar yang dilakukan guru pada pelajaran Matematika. Banyak ditemukan berbagai macam kendala ketika guru menerangkan konsep perkalian dan pembagian. Karena materi tersebut merupakan materi dasar di kelas II, jadi guru perlu menanamkan konsep dengan menggunakan berbagai strategi agar siswa dapat memahami dengan benar. Kegiatan selanjutnya meliputi kegiatan merumuskan tujuan pembelajaran, menyusun langkah-langkah pembelajaran, merencanakan teknik pembelajaran yang sesuai dengan situasi dan kondisi siswa. Dalam hal ini peneliti menggunakan metode kooperatif model team games tournament, serta menyusun tugas sesuai dengan kompetensi yang hendak dicapai. Selanjutnya melaksanakan proses pembelajaran dalam siklus I .

b. Pemberian Tindakan II

Peneliti melaksanakan pembelajaran dengan metode kooperatif model team games tournament. Dengan langkahlangkah kegiatan sebagai berikut.

1. Menjelaskan konsep perkalian dan pembagian.

2. Membagi siswa dalam bentuk kelompok.

3. Memberi tugas kelompok yaitu penjumlahan berulang, dan mencatat hasilnya.

4. Masing-masing anak mencari hasil penjumlahan berulang, dengan cara 
bertukar pekerjaan dengan kelompok lain.

5. Setiap anak dalam kelompok tersebut mencatat hasil penjumlahan berulang yang diterima dari kelompok lain

6. Dari data yang sudah diolah tersebut masing-masing anak menuliskan penjumlahan berulang menjadi perkalian yang hasilnya sama.

c. Melakukan Observasi

Pada waktu pelaku tindakan atau guru mengajar, anggota team peneliti yang lain melakukan observasi dan mencatat kejadian-kejadian selama kegiatan pembelajaran berlangsung. Poin-poin yang diobservasi adalah sebagai berikut:

Tabel 1. Pengelolaan Pembelajaran Pada Siklus I

\begin{tabular}{|c|c|c|c|}
\hline \multirow{2}{*}{ Aspek yang diamati } & \multicolumn{2}{|c|}{ Penilaian } & \multirow{2}{*}{$\begin{array}{l}\text { Rata } \\
\text {-rata }\end{array}$} \\
\hline & $\mathrm{P} 1$ & $\mathrm{P} 2$ & \\
\hline \multicolumn{4}{|l|}{ Pengamatan KBM } \\
\hline \multicolumn{4}{|l|}{ A. Pendahuluan } \\
\hline $\begin{array}{l}\text { 1. Memotivasi } \\
\text { siswa }\end{array}$ & 3 & 3 & 3 \\
\hline $\begin{array}{l}\text { 2. Menyampaikan } \\
\text { tujuan } \\
\text { pembelajaran }\end{array}$ & 2 & 2 & 2 \\
\hline $\begin{array}{l}\text { 3. Menghubungkan } \\
\text { dengan pelajaran } \\
\text { sebelumnya }\end{array}$ & 3 & 4 & 3,5 \\
\hline $\begin{array}{l}\text { 4. Mengatur siswa } \\
\text { dalam } \\
\text { kelompok- } \\
\text { kelompok } \\
\text { belajar }\end{array}$ & 3 & 3 & 3 \\
\hline \multicolumn{4}{|l|}{ B. Kegiatan inti } \\
\hline $\begin{array}{l}\text { 1. Mempresentasik } \\
\text { an langkah- } \\
\text { langkah metode } \\
\text { pembelajaran } \\
\text { kooperatif }\end{array}$ & 2 & 2 & 2 \\
\hline $\begin{array}{l}\text { 2. Membimbing } \\
\text { siswa melakukan } \\
\text { kegiatan }\end{array}$ & 3 & 3 & 3 \\
\hline $\begin{array}{l}\text { 3. Melatih } \\
\text { keterampilan } \\
\text { kooperatif }\end{array}$ & 3 & 3 & 3 \\
\hline $\begin{array}{l}\text { 4. Mengawasi } \\
\text { setiap kelompok } \\
\text { secara bergiliran }\end{array}$ & 2 & 2 & 2 \\
\hline $\begin{array}{l}\text { 5. Memberikan } \\
\text { bantuan kepada } \\
\text { kelompok yang } \\
\text { mengalami } \\
\text { kesulitan } \\
\end{array}$ & 3 & 3 & 3 \\
\hline
\end{tabular}

\begin{tabular}{lccc}
\hline \multirow{2}{*}{ Aspek yang diamati } & \multicolumn{2}{c}{ Penilaian } & Rata \\
\cline { 2 - 3 } & P1 & P2 & -rata \\
\hline $\begin{array}{l}\text { C. Penutup } \\
\text { 1. Membimbing } \\
\quad \begin{array}{l}\text { siswa membuat } \\
\text { rangkuman }\end{array}\end{array}$ & 3 & 3 & 3 \\
$\begin{array}{l}\text { Memberikan } \\
\text { evaluasi }\end{array}$ & 3 & 3 & 3 \\
\hline Pengelolaan Waktu & 2 & 2 & 2 \\
\hline Antusiasme Kelas & & & \\
$\quad \begin{array}{l}\text { 1. Siswa antusias } \\
\text { 2. Guru antusias }\end{array}$ & 2 & 2 & 2 \\
\hline Jumlah & 3 & 3 & 3 \\
\hline
\end{tabular}

Keterangan :

Nilai : Kriteria

1) : Tidak Baik

2) : Kurang Baik

3) : Cukup Baik

4) : Baik

Berdasarkan tabel di atas aspekaspek yang mendapatkan kriteria kurang baik adalah memotivasi siswa, menyampaikan tujuan pembelajaran, pengelolaan waktu, dan antusias siswa. Keempat aspek yang mendapat nilai kurang baik di atas, merupakan suatu kelemahan yang terjadi pada siklus I dan akan dijadikan bahan kajian untuk refleksi dan revisi yang akan dilakukan pada siklus II.

d. Penyusunan Analisis dan Refleksi

Kegiatan analisis dan refleksi ini bertujuan untuk mengetahui tingkat keberhasilan peneliti. Di samping itu untuk mengetahui kelemahan-kelemahan pada sistem atau teknik pembelajaran yang dilakukan oleh peneliti pada siklus I, dan untuk menentukan langkah-langkah perbaikan dalam proses pembelajaran yang akan diterapkan pada siklus II. Dari hasil observasi yang dilakukan pada tindakan I ditemukan beberapa hal sebagai berikut.

1. Penguasaan siswa dalam memahami tugas belum jelas

2. Kegiatan games/permainan masih belum memberikan hasil yang maksimal, hal ini disebabkan karena 
informasi awal yang disampaikan guru kurang dipahami oleh siswa.

3. Siswa belum bisa melaksanakan kegiatan dengan tepat.

4. Siswa belum memaksimalkan kegiatan kerja kelompoknya.

Tabel 2 Perolehan Nilai Siklus I

\begin{tabular}{cccc}
\hline No & Nilai & Jumlah Siswa & Prosentase \\
\hline 1 & 6 & 14 & 46,7 \\
\hline 2 & 7 & 12 & 40 \\
\hline 3 & 8 & 4 & 13,3 \\
\hline Jumlah & 30 & 100 \\
\hline
\end{tabular}

Selanjutnya berikut adalah grafik jumlah siswa yang memperoleh nilai 6,7,8.

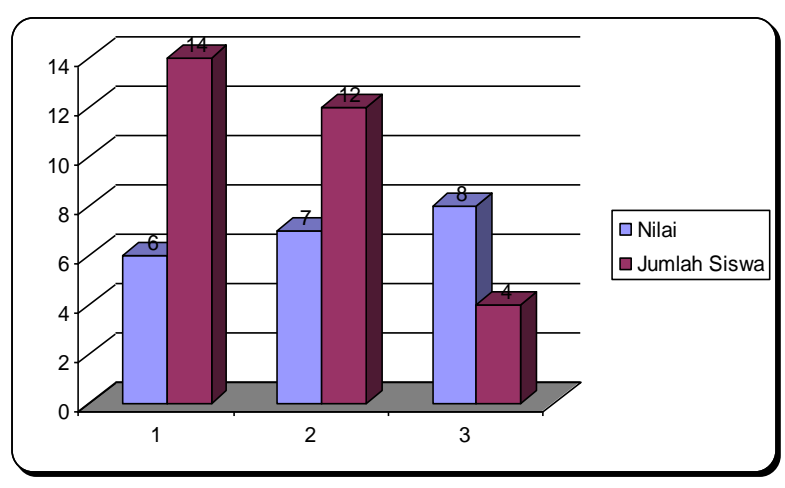

Gambar 1. Perbandingan nilai siswa

Dari tabel di atas dapat dijelaskan bahwa dengan menerapkan metode pembelajaran kooperatif model TGT diperoleh nilai rata-rata prestasi belajar siswa adalah 6,6. dan ketuntasan belajar mencapai $53,3 \%$ atau ada 16 siswa dari 30 siswa sudah tuntas belajar. Hasil tersebut menunjukkan bahwa pada siklus pertama secara klasikal siswa belum tuntas belajar, karena siswa yang memperoleh nilai $\geq 7$ hanya sebesar 13,3\% lebih kecil dari persentase ketuntasan yang dikehendaki yaitu sebesar 75\%. Hal ini disebabkan karena materi tersebut merupakan materi baru dan guru belum menguasai metode pembelajaran kooperatif model TGT.

\section{Siklus 2}

Siklus II dilaksanakan dengan 2 kali pertemuan. Adapun langkah dalam pelaksanaan siklus 2 adalah sebagai berikut:

a. Menyusun Rencana T'indakan II

Rencana tindakan II disusun berdasarkan hasil dari analisis dan refleksi dari siklus I. Guru memperbaiki teknik penyampaian informasinya, menyempurnakan teknik team games tournamentnya, serta menyiapkan materi dengan matang agar dalam siklus ini terjadi peningkatan kemampuan siswa.

b. Pemberian Tindakan II

Pada tahapan ini, tindakan yang dilakukan sesuai dengan yang telah direncanakan dan pada dasarnya hampir sama dengan siklus I. Peneliti atau guru meningkatkan dan memaksimalkan teknik dan strategi pembelajarannya.

c. Pelaksanaan Observasi

Tahapan ini dilaksanakan bersamaan yaitu pada proses pembelajaran atau tahap tindakan. Pada kegiatan ini tim peneliti membuat catatan harian secara rinci, tentang segala respon siswa dan semua peristiwa yang terjadi di kelas selama proses belajar mengajar berlangsung.

Hasil belajar siswa pada siklus II dapat dinyatakan dalam tabulasi data sebagai berikut.

Pada siklus II ini terdapat peningkatan yang sangat signifikan dari guru maupun siswa. Kendala-kendala yang muncul pada siklus I sudah tidak nampak lagi. Karena guru sudah memperbaiki kelemahan-kelemahan dalam pembelajaran pada siklus I.

Namun masih ada beberapa aspek yang mendapatkan kriteria kurang baik, yaitu: menyampaikan tujuan pembelajaran, mengawasi setiap kelompok secara bergiliran dan pengelolaan waktu. Ketiga aspek yang mendapat nilai kurang pada siklus I, telah diperbaiki oleh guru, sehingga ada peningkatan skor yang 
diperoleh peneliti/guru dari pengamat I dan II.

c. Penyusunan Analisis dan Refleksi

Pada siklus II ini sudah ada peningkatan hasil pembelajaran, meskipun masih ada beberapa hal yang harus ditingkatkan misalnya dalam hal penyampaian tujuan, pengelolaan waktu dan pengawasan serta motivasi dalam kelompok-kelompok. Kemampuan guru dalam menguasai materi pembelajaran sudah ada peningkatan, tetapi yang paling utama dalam pembelajaran ini adalah kemampuan guru dalam mengatur dan mengendalikan games, sehingga tujuan dari kompetensi dasar dapat dicapai dengan baik. Dalam siklus II ada dua pencapaian siswa yaitu sebagai berikut.

1. Siswa sudah bisa membuat perkalian dengan penjumlahan berulang.

2. Siswa dapat melakukan kegiatan kerja kelompok dengan baik.

Tabel 3. Perolehan Nilai Siklus II

\begin{tabular}{cccc}
\hline No & Nilai & Jumlah Siswa & Prosentase \\
\hline 1 & 8 & 20 & 66,67 \\
\hline 2 & 9 & 7 & 23,33 \\
\hline 3 & 10 & 3 & 10,00 \\
\hline \multicolumn{2}{c}{ Jumlah } & 30 & 100 \\
\hline
\end{tabular}

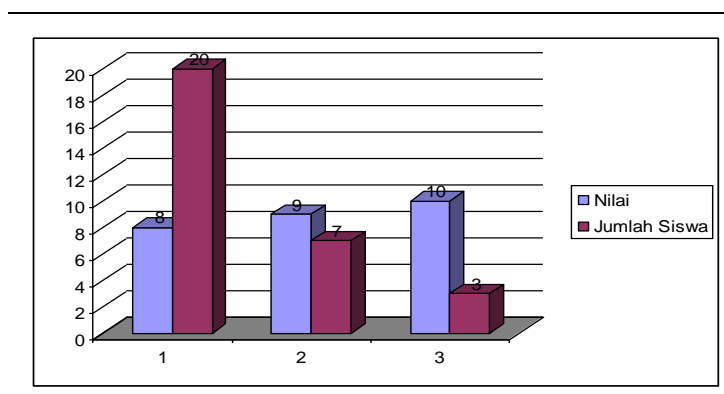

Gambar 2. Grafik Perolehan Nilai Siklus 2

\section{Pembahasan Antar Siklus}

Hasil penelitian menunjukan bahwa ada peningkatan kemampuan pada diri siswa terhadap materi pengolahan dan penyajian data. Pembelajaran dengan metode kooperatif model Team Games Tournament sangat menyenangkan. Suasana pembelajaran yang menyenangkan ternyata memberi motivasi tersendiri bagi siswa dalam belajar Matematika.

Pada siklus I, cara guru mengajar dengan menggunakan dengan metode kooperatif model Team Games Tournament adalah dengan cara memberi variasi dalam melaksanakan tugas yaitu kelompok dan individu. Sebelumnya guru atau peneliti sudah menyiapkan beberapa tugas yang harus dikerjakan oleh siswa. Guru memberikan konsep dasar dulu yaitu cara perkalian dengan penjumlahan berulang. Pada siklus I ini hasilnya belum sesuai denga harapan guru. Hal ini disebabkan mungkin dalam memberikan instruksi pada siswa kurang maksimal, informasi kurang jelas, maka pemahaman siswa juga kurang. Kendala-kendala kekurangberhasilan guru tersebut diperoleh dari observasi yang dilakukan oleh teman kolaborasinya. Kemudian diadakan perbaikan-perbaikan dalam menyusun rencana pembelajaran yang akan dilakukan pada siklus II.

Pada siklus II ada peningkatan yang sangat signifikan. Guru mengulangi lagi pembelajaran seperti pada siklus I, perencanaan guru dalam memberikan materi pembelajaran lebih matang. Games yang dilakukan siswa sudah berjalan sesuai dengan harapan dan siswa dapat bekerja dengan lebih bersemangat. Siswa juga lebih antusias dalam mengikuti pelajaran, dalam pengaturan waktu dan pemantauan pada saat kerja kelompok sudah lebih maksimal. Kolaborasi dengan anggota team sangat membantu peneliti untuk memperbaiki setiap kekurangan yang ada sehingga dapat meningkatkan hasil dan kualitas pembelajaran.

Pada siklus II guru telah menerapkan metode pembelajaran kooperatif model TGT dengan baik. Hal 
ini dilihat dari aktivitas siswa serta hasil belajar yang diperoleh guru. Tidak diperlukan revisi terlalu banyak, tetapi yang perlu diperhatikan tindakan selanjutnya yaitu memaksimalkan dan mempertahankan apa yang telah dicapai.

Melalui hasil penelitian ini menunjukkan bahwa pembelajaran kooperatif model TGT dapat meningkatkan prestasi belajar siswa. Hal ini dapat dilihat dari semakin mantapnya pemahaman siswa terhadap materi yang disampaikan guru (ketuntasan belajar meningkat dari siklus I, dan II.) . Pada siklus II ketuntasan belajar siswa secara klasikal telah tercapai.

Berdasarkan analisis data, diperoleh aktivitas siswa dalam proses metode pembelajaran kooperatif model TGT dalam setiap siklus mengalami peningkatan. Hal ini dapat ditunjukkan dengan meningkatnya nilai rata-rata siswa pada setiap siklus.

Aktivitas siswa dalam proses pembelajaran matematika kompetensi dasar perkalian dan pembagian dengan metode pembelajaran kooperatif model TGT yang paling dominan adalah bekerja dengan menggunakan alat/media, mendengarkan/memperhatikan penjelasan guru, dan diskusi antar siswa/antara siswa dengan guru. Jadi dapat dikatakan bahwa aktivitas siswa dapat dikategorikan aktif.

Sedangkan untuk aktivitas guru selama pembelajaran telah melaksanakan langkah-langkah metode pembelajaran kooperatif model TGT dengan baik. Hal ini terlihat dari aktivitas guru yang muncul di antaranya aktivitas membimbing dan mengamati siswa dalam mengerjakan kegiatan menemukan konsep, menjelaskan materi yang sulit, memberi umpan balik/evaluasi/tanya jawab dimana prosentase untuk aktivitas di atas cukup besar.

Pada tahap ini akan dikaji apa yang telah terlaksana dengan baik maupun yang masih kurang baik dalam proses belajar mengajar dengan penerapan metode pembelajaran kooperatif model TGT. Dari data-data yang telah diperoleh dapat diuraikan sebagai berikut.

1. Selama proses pembelajaran guru telah melaksanakan semua pembelajaran dengan baik. Meskipun ada beberapa aspek yang belum sempurna, tetapi prosentase pelaksanaannya untuk masing-masing aspek cukup besar.

2. Berdasarkan data hasil pengamatan diketahui bahwa siswa aktif selama proses belajar berlangsung.

3. Kekurangan pada siklus sebelumnya sudah mengalami perbaikan dan peningkatan sehingga menjadi lebih baik.

4. Hasil belajar siswa pada siklus II mencapai ketuntasan $100 \%$.

\section{SIMPULAN}

Dari hasil kegiatan pembelajaran yang telah dilakukan selama dua siklus, dan berdasarkan seluruh pembahasan serta analisis yang telah dilakukan dapat disimpulkan bahwa pembelajaran dengan kooperatif model TGT dapat meningkatkan prestasi belajar siswa yang ditandai dengan peningkatan ketuntasan belajar siswa dalam setiap siklus. Hal tersebut ditandai dengan meningkatnya rata-rata keberhasilan siswa pada tiap-tiap siklus yaitu siklus I rata-rata 6,6 menjadi 8,4 pada siklus II.

\section{DAFTAR RUJUKAN}

Juniarso, T. (2008). Sistematika dan Penjelasan Penelitian Tindakan 
Kelas. (trimanunipa@yahoo.com diakses tanggal 1 Maret 2008).

KBBI. (1996). Edisi Kedua, Jakarta: Balai Pustaka.

Kiranawati. (2007). metode Team Games Tournament (TGT). .(http://gurupkn.wordpress.com/20 07/11/13/metode-team-games- tournament-tgt diakses tanggal 13 Nopember 2007).

Lie, A. (2004). Cooperative Learning Mempraktikkan Cooperative Learning di Ruang-Ruang Kelas, Jakarta: Garsindo.

Masrukan. (2004). Matematika dan Alat Peraga. Majalah Fasilitator, edisi IV hal 32. 